\title{
GMR
}

\section{Industrial tomato lines: morphological properties and productivity}

\author{
J.V.M. Peixoto ${ }^{1}$, C. de M.S. Neto ${ }^{2}$, L.F.C. Campos ${ }^{2}$, W. de S. Dourado ${ }^{2}$, \\ A.P.O. Nogueira ${ }^{1}$ and A. dos R. Nascimento ${ }^{2}$ \\ ${ }^{1}$ Universidade Federal de Uberlândia, Campus Umuarama, Uberlândia, \\ MG, Brasil \\ ${ }^{2}$ Universidade Federal de Goiás, Campus Samambaia, Goiânia, GO, Brasil \\ Correponding author: J.V.M. Peixoto \\ E-mail: joicyvmpeixoto@yahoo.com.br
}

Genet. Mol. Res. 16 (2): gmr16029540

Received November 17, 2016

Accepted February 17, 2017

Published April 13, 2017

DOI http://dx.doi.org/10.4238/gmr16029540

Copyright (C 2017 The Authors. This is an open-access article distributed under the terms of the Creative Commons Attribution ShareAlike (CC BY-SA) 4.0 License.

\begin{abstract}
The tomato is the second most produced vegetable in the world, with significant participation in the human diet. In addition, the production of tomatoes generates jobs and family income. The availability of improved cultivars that provide greater profitability to the producer and satisfactorily meets the needs of the fresh fruit market and the processing industry becomes imperative due to its importance. Therefore, this study aimed to characterize and select industrial tomato lines in regard to fruit yield, number of leaf branches, and number of flower racemes (NFR). The experiment was conducted in 2014 in the experimental area of the Federal University of Goiás (Universidade Federal de Goiás). The design was a randomized block design with four replicates and 25 genotypes. The number of leaf branches (NB), NFR, and fruit productivity were evaluated. The results were analyzed using analysis of variance and the means compared by the Tukey test. A difference was observed $(\mathrm{P} \leq 0.01)$ for all traits analyzed. The NB and NFR were related, where more branches promoted an increase in NFR and thus the productivity increases. In addition, a greater number of fruits implied in smaller fruit size, and consequently lower fruit mass.
\end{abstract}

Genetics and Molecular Research 16 (2): gmr16029540 
The lowest number of fruit per plant caused increased fruit size and mass. The lines CVR 1, CVR 3, CVR 4, CVR 5, CVR 21, and CVR 22 were suitable for genetic enhancement of tomato and provided the greatest productivity.

Key words: Solanum lycopersicum L.; Genotype selection; Genetic enhancement; Genetic variability; Leaf branches; Flower racemes

\section{INTRODUCTION}

The tomato (Solanum lycopersicum L.) is a fruit rich in several nutrients, including vitamins, with a high nutritional value. The ease and versatility of using this vegetable, as well as the economic and social importance, entail its popularity. Tomato crops employ several workers, both directly and indirectly, generating income for many families involved with producing the fruit. The tomato is low in calories, rich in vitamins A, B, and C, sucrose, fructose, lipid, protein, and minerals such as phosphorus, calcium, potassium, and magnesium (Alvarenga, 2013). This fruit also has antioxidant molecules such as ascorbic acid, vitamin E, carotenoids, and phenolic compounds (George et al., 2004), thus being considered a functional food. There is evidence that the regular intake of this fruit minimizes the risk of cardiovascular diseases and different cancers (Kris-Etherton et al., 2002). The nutritional value and health benefits favor the in natura and industrial marketing of the product.

Tomato production in Brazil was 4.1 million tons in 2013, falling behind only China, United States, and Turkey. The State of Goiás is the largest tomato producer in Brazil (1.2 million tons, or $32.1 \%$ of the total produced fruit), ahead of São Paulo (17.6\%), Minas Gerais (13.5\%), Paraná (7.3\%), Bahia (5.1\%), and Rio de Janeiro (4.7\%) (IBGE, 2013). In 2015, the State of Goiás produced 904 thousand tons of fruit, for which the harvested area was 10,381 hectares (AGRIANUAL, 2016).

The tomato culture has undergone major transformations in the last decade, which consisted on the mechanization of transplanting and harvesting, overall improvement of the production system, and intensive use of hybrids with high productivity and "long-life" fruit. The identification of tomato cultivars that combine high yield, nutritional quality, and good external appearance of the fruit destined for fresh consumption is important. Such characteristics, associated with the growth habit determined to the use of areas or periods adverse for stacked crops and with resistance to pathogens harmful to the culture, assist the producer in maximizing the results. Reducing the cost of production by producing quality fruit facilitates the introduction of the product into the market (Seleguini, 2007).

Quantitative characteristics, such as plant height, number of leaf branches, number of flower racemes (NFR), number of flowers per raceme, productivity, among others, are important attributes in tomato enhancement. The tomato plant has several quantitative characters that can be used in genetic evaluation, resulting in highly homogeneous genotypes, which are highly favorable for culture enhancement (Narolia et al., 2012). Qualitative and quantitative traits are controlled by gene action, and are thus important in genotype selection. The number of branches (NB) per plant, number of days for 50\% flowering, plant height, and average fruit weight are quantitative traits (Mohamed et al., 2012).

Knowledge on the relationship between yield, its components, and the interrelationship between components can provide information that is important for effective and successful

Genetics and Molecular Research 16 (2): gmr16029540 
reproduction in genetic enhancement programs (Mahapatra et al., 2013). Therefore, the association between branches and racemes, and productivity is used as a strategy for the genetic enhancement of plants, in order to select genotypes with desirable traits at an early stage. The number of primary branches and flowers per raceme contributes to the fruit yield per plant (Reddy et al., 2013).

The coefficient of phenotypic variation (CPV) in tomato plants has been reported to be higher compared to the coefficient of genotypic variation (CGV) (Tiwari et al., 2013). These authors reported a higher CPV in fruit weight (29.86\%), fruit diameter $(22.79 \%)$, and NB per plant $(20.76 \%)$, where fruit yield per hectare had the lowest coefficient recorded $(5.30 \%)$. The highest CGV was recorded in fruit weight (28.29\%) followed by fruit diameter $(18.45 \%)$ and NB per plant (14.96\%), while fruit yield per hectare had the lowest value (3.97\%). These authors also recorded high heritability and consequently less influence of environmental factors on fruit weight $(89.90 \%)$, number of days for fruit to reach the green maturity stage $(87.60 \%), 50 \%$ of flowering plants $(80.6 \%)$, and number of days for the fruit to reach the red maturity stage $(79.50 \%)$.

The floral racemes, which will originate the fruit, come from opposite buds or between leaves (Nascimento et al., 2012). The association between the NB and the NFR may characterize the relationship between these measures and productivity. Such association is positive given that the increase in the number of leaf branches increases the production of flower racemes and consequently, fruit production per plant, thus increasing productivity. The variables analyzed will enable the selection of genotypes that are adequate to continue the process of genetic enhancement of the studied lines.

Given the context above, the objective of this study was to characterize and select industrial tomato genotypes regarding productivity and the number of leaf branches and NFR.

\section{MATERIAL AND METHODS}

The experiment was conducted at the experimental area of the School of Agronomy (Escola de Agronomia) of Universidade Federal de Goiás in 2014, located at 16³5'48"S and $49^{\circ} 16^{\prime} 53^{\prime \prime} \mathrm{W}$, and at an altitude of $709 \mathrm{~m}$. The soil was characterized as having medium texture, and is categorized as a dystrophic Oxisol (EMBRAPA, 2013). The climate of the region following the Köppen classification is Aw, characterized as Tropical Humid, and has two well-defined seasons, cold dry winter and rainy hot summer. The average precipitation from July to October was $28.42 \mathrm{~mm}$, the average temperature was of $24^{\circ} \mathrm{C}$ and the relative humidity was $59.5 \%$.

A completely randomized block design was used with 25 treatments, namely 22 lines and three hybrids (lines: CVR 01; CVR 02; CVR 03; CVR 04; CVR 05; CVR 06; CVR 07; CVR 08; CVR 09; CVR 10; CVR 11; CVR 12; CVR 13; CVR 14; CVR 15; CVR 16; CVR 17; CVR 18; CVR 19; CVR 20; CVR 21; CVR 22; and hybrids: Kátia, AP-533 and SVR-453), and four replicates. These hybrids of tomato for industrial processing were evaluated for providing fruit with shape similar to that of the Italian type, intended for in natura consumption. The similarity among fruit facilitates commercialization of the tomato established as in natura fruit, which causes inconveniences to professionals of supply stations such as CEASA (Central de Abastecimento de Hortifrutigranjeiros; Central of Fresh Produce Supply).

Each plot $(3 \times 7.5 \mathrm{~m})$ had six rows with six plants, amounting to 36 plants per plot. The used plot $\left(12 \mathrm{~m}^{2}\right)$ comprised the central planting row, where the borders were the first and

Genetics and Molecular Research 16 (2): gmr16029540 
last lateral line, and the initial and final plants of each plot. The tomato plants were sown on July 5 . The substrate used was composed of a mixture of peat and perlite. Sowing was done in polyethylene trays of $11 \mathrm{~cm}^{3}$ with 288 cells. The seeds were sown in an $8 \mathrm{~mm}$ in depth and covered with vermiculite.

The area was prepared on June 28 by plowing, harrowing, and smoothing. A total of $1.0 \mathrm{t} / \mathrm{ha}$ lime dolomitic filler were used following soil analysis and the formula NPK4-30-10 at a dose of $1.0 \mathrm{t} / \mathrm{ha}$ was used as planting fertilizer. Liming was conducted on July 10 , the fertilization on July 11 and the transplanting of seedlings on July 12 at 37 days after sowing. The distance between the plants was $0.50 \mathrm{~m}$ and between lines was $1.5 \mathrm{~m}$. The area was irrigated by through drip, which varied depending on the evapotranspiration of the culture following Doorembos and Kassam (1979).

The integrated pest and disease management was carried out by applying phytosanitary products during the culture cycle. Insecticides and fungicides recommended for the tomato were used.

\section{Characteristics analyzed}

The traits evaluated were number of leaf branches and NFR at 42 and 63 days after transplant (DAT), the difference between the number of leaf branches from 42 DAT to 63 DAT, the difference between NFR from 42 DAT to 63 DAT, and productivity. The number of leaf branches and NFR was obtained randomly sampling eight plants from the experimental area in each plot. The plants were marked with red color string so that both counts were performed on the same plants. Only the secondary stems were counted.

The difference between the number of leaf branches and NFR from 42 to 63 DAT was calculated by subtracting the values obtained at 63 DAT from the observed at 42 DAT. Productivity was determined through manually harvesting eight plants present in the experimental area and then estimated in tons/hectare.

\section{Statistical analysis}

The Kolmogorov-Smirnov, Levene, and block additivity tests were used to assess the normality of the residues, homogeneity of variances, and block additivity. Analysis of variance (ANOVA) was then carried out using the F-test at a 0.05 probability level. The Scott-Knott test was used to compare means also with a 0.05 probability level. The genotypic coefficient of determination, and phenotypic (rp) and genotypic correlations ( $\mathrm{rg}$ ) were determined. A cluster analysis was carried out using the Euclidean distance, following the farthest neighbor method to form groups among the genotypes. A principal components analysis (PCA) was carried out for the NFR, NB, and productivity of the genotypes to verify the relationship among these variables.

The mean test was applied through the Sisvar version 5.6 software (Ferreira, 2011). The PCA and the cluster analysis were carried out using the Past version 2.17software (Hammer et al., 2007). The Genes version 2007 software was used for the heritability and genotypic correlation (Cruz, 2013).

The genotypes were considered fixed because they were evaluated in one place. Thus, heritability is called coefficient of genotypic determination (Cruz et al., 2012). The coefficient of genotypic determination $\left(\mathrm{h}^{2}\right)$ was determined by the estimator

Genetics and Molecular Research 16 (2): gmr16029540 


$$
H^{2}=(\varnothing g / \varnothing F)=[(\varnothing g /(M S G / r)]
$$

(Equation 1)

where $\varnothing \mathrm{g}$ is the genetic variability between lines and tomato hybrids, MSG is the mean square of the genotype, and $\mathrm{r}$ is the number of replicates.

Phenotypic and genotypic correlations were determined, respectively, by the estimators

$$
r_{p}=\frac{M P T_{x y}}{\sqrt{M S T_{x} * M S T_{y}}}
$$

and

$$
r_{g}=\frac{\hat{\sigma}_{g x y}}{\sqrt{\hat{\sigma}_{g x}^{2} * \hat{\sigma}_{g y}^{2}}}
$$

Where MPT is the mean product of the treatment, MST is the mean square of the treatments, $\mathrm{X}$ and $\mathrm{Y}$ are traits evaluated, $\hat{\sigma}_{g x y}$ is the estimator of genotypic covariance between $\mathrm{X}$ and $\mathrm{Y}$, and $\hat{\sigma}_{g x}^{2}$ and $\hat{\sigma}_{g y}^{2}$ are estimators of genotypic variances between $\mathrm{X}$ and $\mathrm{Y}$, respectively (Cruz et al., 2012).

The Euclidean distance was used as the dissimilarity measure through the equation

$$
d i i^{\prime}=\left\{\sqrt{\left[\Sigma_{j}\left(X_{i j}-X_{i^{\prime} j}\right)^{2}\right]}\right\}
$$

where $\mathrm{X}_{\mathrm{ij}}$ is the observation in the $i$ th progenitor $(\mathrm{I}=1,2, \ldots, \mathrm{p})$, in regard to the $j$ th trait $(\mathrm{j}=1$, $2, \ldots, n$ ) evaluated, and $i$ and $i '=$ are progenitors (Cruz et al., 2012).

The farthest neighbor method in the cluster analysis uses

$$
d_{(i j) k}=\max \left\{d_{i k} ; d_{j k}\right\} \text { as estimator, }
$$

where $\mathrm{d}_{(\mathrm{ij}) \mathrm{k}}$ is given by the largest element of the set of distances among parent pairs $(i$ and $k$ ) and $(j$ and $k$ ). The distance between two groups is obtained by

$$
d(i j)(k l)=\max \left\{d_{i k} ; d_{i l} ; d_{j k} ; d_{j l}\right\}
$$

i.e., the distance between two groups formed, respectively, by the progenitors ( $i$ and $j)$ and $(k$ and $l$ ) is given by the largest element of the set whose elements are the distances between the pairs of progenitors $(i$ and $k),(i$ and $l),(j$ and $k)$, and ( $j$ and $l$ ) (Cruz et al., 2012).

\section{RESULTS AND DISCUSSION}

The genotypes differed in regard to the number of leaf branches and NFR at 42 DAT, NB and NFR at 63 DAT, and also in the development among the respective dates (Table 1).

Genetics and Molecular Research 16 (2): gmr16029540 
Table 1. Average number of branches (NB) and of flower racemes (NFR) in industrial tomato genotypes.

\begin{tabular}{|c|c|c|c|c|c|c|}
\hline \multirow[t]{3}{*}{ Genotypes $^{1}$} & \multicolumn{6}{|c|}{ Evaluations } \\
\hline & \multicolumn{2}{|c|}{$42 \mathrm{DAT}$} & \multicolumn{2}{|c|}{63 DAT } & \multicolumn{2}{|c|}{ Dif. 63 DAT and 42 DAT $^{2}$} \\
\hline & Average NB & Average NFR & Average $^{1} \mathrm{NB}$ & Average NFR & Average NB & Average NFR \\
\hline CVR 1 & $6.59^{\mathrm{b}}$ & $7.88^{\mathrm{b}}$ & $8.75^{\mathrm{b}}$ & $22.91^{\mathrm{c}}$ & $2.16^{\mathrm{b}}$ & $15.03^{\mathrm{c}}$ \\
\hline CVR 2 & $6.97^{\mathrm{b}}$ & $10.66^{\mathrm{a}}$ & $10.09^{\mathrm{b}}$ & $29.19^{\mathrm{b}}$ & $3.12^{\mathrm{b}}$ & $18.53^{\mathrm{b}}$ \\
\hline CVR 3 & $7.50^{\mathrm{a}}$ & $9.84^{\mathrm{a}}$ & $10.59^{\mathrm{b}}$ & $27.56^{\mathrm{b}}$ & $3.09^{\mathrm{b}}$ & $17.72^{\mathrm{b}}$ \\
\hline CVR 4 & $7.94^{\mathrm{a}}$ & $13.56^{\mathrm{a}}$ & $11.91^{\mathrm{a}}$ & $34.75^{\mathrm{a}}$ & $3.97^{\mathrm{a}}$ & $21.19^{\mathrm{a}}$ \\
\hline CVR 5 & $7.40^{\mathrm{a}}$ & $11.66^{\mathrm{a}}$ & $10.06^{\mathrm{b}}$ & $22.47^{\mathrm{c}}$ & $2.66^{\mathrm{b}}$ & $10.81^{\mathrm{c}}$ \\
\hline CVR 6 & $7.53^{\mathrm{a}}$ & $10.53^{\mathrm{a}}$ & $9.12^{\mathrm{b}}$ & $22.75^{\mathrm{c}}$ & $1.59^{\mathrm{b}}$ & $12.22^{\mathrm{c}}$ \\
\hline CVR 7 & $7.81^{\mathrm{a}}$ & $11.53^{\mathrm{a}}$ & $10.72^{\mathrm{b}}$ & $28.28^{\mathrm{b}}$ & $2.91^{\mathrm{b}}$ & $16.75^{\mathrm{b}}$ \\
\hline CVR 8 & $7.03^{\mathrm{b}}$ & $8.94^{\mathrm{b}}$ & $9.72^{\mathrm{b}}$ & $25.31^{\mathrm{c}}$ & $2.69^{\mathrm{b}}$ & $16.37^{\mathrm{b}}$ \\
\hline CVR 9 & $5.81^{\mathrm{b}}$ & $8.31^{\mathrm{b}}$ & $9.72^{\mathrm{b}}$ & $28.06^{\mathrm{b}}$ & $3.91^{\mathrm{a}}$ & $19.75^{\mathrm{b}}$ \\
\hline CVR 10 & $6.72^{\mathrm{b}}$ & $11.09^{\mathrm{a}}$ & $9.59^{\mathrm{b}}$ & $33.34^{\mathrm{a}}$ & $2.87^{\mathrm{b}}$ & $22.25^{\mathrm{a}}$ \\
\hline CVR 11 & $6.90^{\mathrm{b}}$ & $10.94^{\mathrm{a}}$ & $10.25^{b}$ & $28.78^{\mathrm{b}}$ & $3.35^{\mathrm{b}}$ & $17.84^{b}$ \\
\hline CVR 12 & $7.22^{\mathrm{a}}$ & $10.34^{\mathrm{a}}$ & $12.78^{\mathrm{a}}$ & $34.69^{\mathrm{a}}$ & $5.56^{\mathrm{a}}$ & $24.35^{\mathrm{a}}$ \\
\hline CVR 13 & $6.31^{\mathrm{b}}$ & $7.34^{\mathrm{b}}$ & $10.62^{\mathrm{b}}$ & $31.00^{\mathrm{a}}$ & $4.31^{\mathrm{a}}$ & $23.66^{\mathrm{a}}$ \\
\hline CVR 14 & $7.28^{\mathrm{a}}$ & $9.66^{\mathrm{a}}$ & $11.44^{\mathrm{a}}$ & $34.44^{\mathrm{a}}$ & $4.16^{\mathrm{a}}$ & $24.78^{\mathrm{a}}$ \\
\hline CVR 15 & $6.84^{\mathrm{b}}$ & $7.66^{\mathrm{b}}$ & $12.06^{\mathrm{a}}$ & $34.34^{\mathrm{a}}$ & $5.22^{\mathrm{a}}$ & $26.68^{\mathrm{a}}$ \\
\hline CVR 16 & $6.78^{\mathrm{b}}$ & $8.54^{\mathrm{b}}$ & $12.25^{\mathrm{a}}$ & $34.16^{\mathrm{a}}$ & $5.47^{\mathrm{a}}$ & $25.62^{\mathrm{a}}$ \\
\hline CVR 17 & $6.59^{\mathrm{a}}$ & $8.63^{\mathrm{b}}$ & $10.12^{\mathrm{b}}$ & $26.25^{\mathrm{b}}$ & $3.53^{\mathrm{b}}$ & $17.62^{b}$ \\
\hline CVR 18 & $7.09^{\mathrm{b}}$ & $9.87^{\mathrm{a}}$ & $11.09^{\mathrm{a}}$ & $31.81^{\mathrm{a}}$ & $4.00^{\mathrm{a}}$ & $21.94^{\mathrm{a}}$ \\
\hline CVR 19 & $8.06^{\mathrm{a}}$ & $10.84^{\mathrm{a}}$ & $12.66^{\mathrm{a}}$ & $28.81^{\mathrm{b}}$ & $4.60^{\mathrm{a}}$ & $17.97^{\mathrm{b}}$ \\
\hline CVR 20 & $7.31^{\mathrm{a}}$ & $10.40^{\mathrm{a}}$ & $12.06^{\mathrm{a}}$ & $28.81^{\mathrm{b}}$ & $4.75^{\mathrm{a}}$ & $18.41^{b}$ \\
\hline CVR 21 & $7.63^{\mathrm{a}}$ & $10.16^{\mathrm{a}}$ & $12.94^{\mathrm{a}}$ & $34.47^{\mathrm{a}}$ & $5.31^{\mathrm{a}}$ & $24.31^{\mathrm{a}}$ \\
\hline CVR 22 & $7.00^{\mathrm{b}}$ & $9.25^{\mathrm{b}}$ & $11.78^{\mathrm{a}}$ & $31.15^{\mathrm{a}}$ & $4.78^{\mathrm{a}}$ & $21.90^{\mathrm{a}}$ \\
\hline AP-533* & $7.81^{\mathrm{a}}$ & $10.60^{\mathrm{a}}$ & $12.34^{\mathrm{a}}$ & $31.97^{\mathrm{a}}$ & $4.53^{\mathrm{a}}$ & $21.37^{\mathrm{a}}$ \\
\hline SVR-0453* & $8.09^{\mathrm{a}}$ & $11.85^{\mathrm{a}}$ & $11.22^{\mathrm{a}}$ & $26.19^{\mathrm{b}}$ & $3.13^{\mathrm{b}}$ & $14.34^{\mathrm{c}}$ \\
\hline Kátia* & $7.84^{\mathrm{a}}$ & $9.66^{\mathrm{a}}$ & $12.22^{\mathrm{a}}$ & $33.69^{\mathrm{a}}$ & $4.38^{\mathrm{a}}$ & $24.03^{\mathrm{a}}$ \\
\hline $\mathrm{CV} \%$ & 11.88 & 16.78 & 11.06 & 10.98 & 26.84 & 15.51 \\
\hline
\end{tabular}

Means followed by the same letters in the column do not differ by the Scott-Knott test, at $5 \%$ probability. ${ }^{1}$ LinesCVR Plant Breeding Ltda. *Experimental hybrids AP-533, SVR-0453 (Seminis do Brasil), and Kátia (Hazera Seeds). ${ }^{2}$ Dif. 63 DAT and 42 DAT $=$ difference between the number of leaf branches and flower racemes, respectively, from 42 days after transplant to 63 days after transplant. $\mathrm{CV} \%=$ coefficient of variation.

Differences in the NB and 42 DAT were detected $(\mathrm{P} \leq 0.05$; Table 1$)$ between the genotype groups CVR 3, CVR 4, CVR 5, CVR 6, CVR 7, CVR 12, CVR 14, CVR 17, CVR 19, CVR 20, CVR 21, AP-533, SVR-0453, Kátia and the strain groups CVR 1, CVR 2, CVR 8, CVR 9, CVR 10, CVR 11, CVR 13, CVR 15, CVR 16, CVR 18, and CVR 22. The first group had a higher amount of leaf branches (on average 7.22 to 8.09) when compared to the second group (on average 5.81 to 7.09 ).

The variable NFR differed at 42 DAT $(\mathrm{P} \leq 0.01$; Table 1$)$. The genotypes CVR 2, CVR 3, CVR 4, CVR 5, CVR 6, CVR 7, CVR 10, CVR 11, CVR 12, CVR 14, CVR 18, CVR 19, CVR 20, CVR 21, AP-533, SVR-0453, and Kátia did not differ from each other. However, these aforementioned genotypes have a higher amount of flower racemes (on average 9.66 to 13.56) than the lines 1, CVR 8, CVR 9, CVR 13, CVR 15, CVR 16, CVR 17, and CVR 22 (on average 7.34 to 9.25 flower racemes per plant).

The genotypes CVR 4, CVR 12, CVR 14, CVR 15, CVR 16, CVR 18, CVR 19, CVR 20, CVR 21, CVR 22, AP-533, SVR-0453, and Kátia at 63 DAT (Table 1) differed from the lines $(\mathrm{P} \leq 0.01)$ CVR 1, CVR 2, CVR 3, CVR 5, CVR 6, CVR 7, CVR 8, CVR 9, CVR 10, CVR 11, CVR 13, and CVR 17, which provided the least amount of leaf branches.

A experiment carried out with 22 tomato hybrids reported the highest NB per plant at 60 DAT for the hybrid US 1196 (14.82), US 618 (14.37), Heem Sohna (14.15), All Rounder (12.98), US 2175 (15.23), and Anup (14.03) and the least number for COTH 2 (10.32) (Raju 
et al., 2014). The same experiment recorded the highest NB per plant at 63 DAT for the strain CVR 21 (12.94 branches).

The NFR at 63 DAT (Table 1) differed among genotypes $(\mathrm{P} \leq 0.01)$. The first group (CVR 4, CVR 10, CVR 12, CVR 13, CVR 14, CVR 15, CVR 16, CVR 18, CVR 21, CVR 22, AP-533, and Kátia) had a higher amount of flower racemes than the other group of genotypes (CVR 2, CVR 3, CVR 7, CVR 9, CVR 11, CVR 17, CVR 19, CVR 20, and SVR-0453) and the lines CVR 1, CVR 5, CVR 6, and CVR 8 exhibited the lowest NFR.

Quintana-Baquero et al. (2010) conducted an experiment with tomatoes of undetermined growth habit in the municipality of Turmequé (Colombia) and observed higher quality (fruit with diameter above $82 \mathrm{~mm}$ ) for those with 10 flower racemes per plant and lower quality for those with 12 flower racemes per plant. However, the higher amount of flower racemes and, consequently, the higher production of fruit, were inversely related with the average weight of the commercial fruit.

In this study, the lines with the highest NFR per plant at 63 days after transplant were CVR 4, CVR 10, CVR 12, CVR 13, CVR 14, CVR 15, CVR 16, CVR 18, CVR 21, CVR 22 and the hybrids Kátia and AP-533. The lines that least produced flower racemes were CVR 8, CVR 1, CVR 6, and CVR 5. The genotype CVR 4 provided the highest average flower racemes (34.75) and the CVR 5 provided the lowest (22.47), with a range of 12.28 flower racemes per plant.

Quintana-Baquero et al. (2010) also reported a linear increase in the total production of tomato crops due to the number of racemes per plant. They obtained a higher production for plants with twelve racemes and a lower production for those with eight racemes. In addition, they observed a direct reduction in fruit size as the flower racemes increased. This study supports those results, where an increase in the production of flower racemes and fruit was observed with the increase in the number of leaf branches.

Fruit growth affects leaf expansion reducing leaf area, which leads to varying fruit sizes. Such pattern occurs due to the competition for assimilates from photosynthesis (Guo et al., 2011). These assimilates are differently distributed among the different organs during plant growth and development. The main drains are the leaves in the vegetative stage and the formation of flowers and fruits in the reproductive phase (Guimarães et al., 2011). A higher amount of flower racemes provide a higher amount, and consequently, smaller fruits. A lower NFR produces less fruit; however, larger and heavier (Quintana-Baquero et al., 2010). In this study, a total of 34.69 flower racemes were recorded at 63 DAT for the strain CVR 12 and 34.47 for CVR 21 . The strain CVR 12 yielded $41.22 \mathrm{t} /$ ha in productivity and the strain CVR 21 , with 0.22 less racemes, had a higher productivity ( $51 \mathrm{t} / \mathrm{ha})$.

Ma et al. (2011) studied six cultivars of Capsicum and peppers, and assessed plants with larger differences in fruit size and in fructification. Results showed that the number of fruits per plant affects fruit size and weight, determining production yield.

The genotypes CVR 4, CVR 9, CVR 12, CVR 13, CVR 14, CVR 15, CVR 16, CVR 18, CVR 19, CVR 20, CVR 21, CVR 22, AP-533, and Kátia exhibited an increase in the number of leaf branches in the respective seasons for NB from 42 DAT to 63 DAT (Table 1). On the other hand, the lines CVR 1, CVR 2, CVR 3, CVR 5, CVR 6, CVR 7, CVR 8, CVR 10, CVR 11, CVR 17, and the hybrid SVR-0453 had a lesser increase in the number of leaf branches. The lines CVR 6 and CVR 12 had the lowest and highest increases in leaf branches, precisely with means of 1.59 and 5.56 , respectively.

The NFR from 42 DAT to 63 DAT (Table 1) differed $(\mathrm{P} \leq 0.01)$ among genotype (CVR

Genetics and Molecular Research 16 (2): gmr16029540 
4, CVR 10, CVR 12, CVR 13, CVR 14, CVR 15, CVR 16, CVR 18, CVR 21, CVR 22, AP533, and Kátia) and strain groups (CVR 2, CVR 3, CVR 7, CVR 8, CVR 9, CVR 11, CVR 17, CVR 19, and CVR 20), and between the genotypes CVR 1, CVR 5, CVR 6, and SVR-0453. The former group showed an increase for NFR, while the latter showed the lesser increase between the periods evaluated. The highest mean (26.68) flower racemes was observed for the strain CVR 15 and the lowest (10.81) for CVR 5, with a range of 15.87.

A research carried out with five types of tomato (Gautam et al., 2013) reported that the NB per plant varied from 7.30 to 7.96 in four varieties. The authors recorded the highest number of racemes per plant (11.90) for the variety Kashi Vishesh followed by Kashi Anupam (11.88).

The coefficient of variation (CV) gives an idea of the precision of the experiment. The $\mathrm{CV}$ obtained in field assays are considered low when below $10 \%$, on average for values between 10 and 20\%, high when ranging from 20 to a 30\%, and very high for values above $30 \%$ (Pimentel-Gomes, 2009). The CV for NB and NFR at 42 DAT and 63 DAT, and the CV of the difference between the NFR in the respective periods were considered to be on average (Table 1), showing that the experiment was well conducted.

Positive and significant ( $1 \%$ probability) correlations were observed between NB and NFR at 42 DAT (0.71), NB at 42 DAT and NB at 63 DAT (0.48; 5\%probability level), NB and NFR at 63 DAT (0.72), NB at 63 DAT and NB (difference: 0.88), NB at 63 DAT and NFR (difference: 0.62), NFR at 63 DAT and NB (difference: 0.78), NFR at 63 DAT and NFR (difference: 0.94 at 1\% probability level) and NB (difference) and NFR (difference: 0.81 at $1 \%$ probability level) (see Table 2 ). The traits NFR at 63 DAT and NFR (difference) exhibited positive genotypic and significant correlation $(0.95)$ at a $5 \%$ probability level.

\begin{tabular}{|c|c|c|c|c|c|c|c|c|}
\hline \multirow[t]{2}{*}{ Trait } & & NB & NFR & NB & NFR & NB & NFR & \multirow[t]{2}{*}{ Prod. } \\
\hline & & \multicolumn{2}{|c|}{42 DAT } & \multicolumn{2}{|c|}{63 DAT } & \multicolumn{2}{|c|}{ Difference } & \\
\hline \multirow[t]{2}{*}{1} & $\mathrm{G}$ & - & 0.82 & 0.47 & -0.54 & 0.12 & -0.30 & 0.32 \\
\hline & $\mathrm{F}$ & - & $0.71^{* *}$ & $0.48^{*}$ & 0.06 & 0.01 & -0.18 & 0.31 \\
\hline \multirow[t]{2}{*}{2} & $\mathrm{G}$ & - & - & 0.12 & -0.11 & -0.20 & -0.40 & -0.03 \\
\hline & $\mathrm{F}$ & - & - & 0.15 & 0.006 & -0.21 & -0.34 & 0.03 \\
\hline \multirow[t]{2}{*}{3} & $\mathrm{G}$ & - & - & - & 0.80 & 0.93 & 0.70 & 0.20 \\
\hline & $\mathrm{F}$ & - & - & - & $0.72 * *$ & $0.88^{* *}$ & $0.62^{* *}$ & 0.21 \\
\hline \multirow[t]{2}{*}{4} & G & - & - & - & - & 0.92 & $0.95^{+}$ & 0.08 \\
\hline & $\mathrm{F}$ & - & - & - & - & $0.78^{* *}$ & $0.94 * *$ & 0.12 \\
\hline \multirow[t]{2}{*}{5} & $\mathrm{G}$ & - & - & - & - & - & 0.91 & 0.09 \\
\hline & $\mathrm{F}$ & - & - & - & - & - & $0.81 * *$ & 0.08 \\
\hline \multirow[t]{2}{*}{6} & $\mathrm{G}$ & - & - & - & - & - & - & 0.08 \\
\hline & $\mathrm{F}$ & - & - & - & - & - & - & 0.09 \\
\hline \multirow[t]{2}{*}{7} & $\mathrm{G}$ & - & - & - & - & - & - & 1.0 \\
\hline & $\mathrm{F}$ & - & $\begin{array}{lll}- & \\
\end{array}$ & - & - & - & - & 1.0 \\
\hline $\mathrm{h}^{2}(\%)$ & & 44.27 & 67.11 & 74.88 & 83.14 & 76.72 & 86.84 & 75.81 \\
\hline
\end{tabular}

NB (42 DAT): number of leaf branches at 42 days after transplant; NFR (42 DAT): number of flower racemes at 42 days after transplant; NB (63 DAT): number of leaf branches at 63 days after transplant; NFR (63 DAT): number of flower racemes at 63 days after transplant; NB (difference): difference between the number of branches at 42 DAT and 63 DAT; NFR (difference): difference between the number of flower racemes at 42 DAT and 63 DAT; Prod: productivity. ${ }^{* * *}$ Significant phenotypic correlation at 1 and $5 \%$ probability, respectively, by the $t$-test ${ }^{+}$Significant genotypic correlation at $5 \%$ probability by the bootstrap method with 5000 iterations.

Understanding the association between traits is fundamental in heritability studies and/or in facing dilemmas in measurement and identification. Phenotypic correlation can be directly measured from the information on two traits, on a certain number of individuals from 
the population. This correlation has genetic and environmental causes, but only the genetic causes are inheritable, and may be used in genetic enhancement programs (Cruz et al., 2012).

The genetic correlation is based mainly on pleiotropy. Pleiotropy is a phenomenon in which the same locus controls different traits (Balestre, 2012). A trait may be favored by the indirect selection of another trait. Therefore, both traits must have a favorable genetic correlation. Therefore, the indirect selection based on the correlated response can lead to more rapid progress when compared to directly selecting the desired character. However, one must be careful in selection when a trait is negatively correlated with some characteristics and positively with others, avoiding undesirable changes in some traits (Cruz et al., 2012).

The amount of leaf branches in tomato plants leads to an increase in the NFR, increasing the number of fruits produced. Mahapatra et al. (2013) have reported a significant and positive correlation (1\% probability) between the NFR per plant and number of fruit per plant. The phenotypic correlation coefficient observed by these authors was 0.70 and the genotypic was 0.712 . The authors reported positive and significant correlation ( $1 \%$ probability level) between the NB, NFR, and fruit per plant. The phenotypic coefficient of correlation between the NB and of NFR per plant was 0.834 and the genotype was 0.858 . The NB and number of fruit per plant yielded a phenotypic correlation coefficient of 0.564 and genotypic of 0.595 . The high genotypic correlation recorded in this study between the NB and NFR at 63 DAT (0.80) supports the correlation observed by Mahapatra et al. (2013) (0.858).

Meena and Bahadur (2015) evaluated nineteen indeterminate tomato accessions and recorded a high positive genotypic and phenotypic correlation (1\% probability) between the NB per plant at 120 DAT and NFR per plant of 0.63 and 0.61 , respectively, and a genotypic and phenotypic correlation between NB at 120 DAT and number of fruit per plant of 0.40 and 0.39 , respectively. These results are in line with the results found in this study, where the genotypic correlations were higher, surpassing estimates of phenotypic correlations that showed significant results.

Productivity is positively and significantly correlated with plant height, NB, NFR, fruit per plant, length and width of fruit, pericarp thickness, number of loci per fruit, average fruit weight, and fruit yield per plant (Mahapatra et al., 2013). The production of fruit per plant has been reported to be positively and significantly correlated (1\% probability level) with the variables number of fruit per plant (0.944), average fruit weight $(0.532 \mathrm{~g})$, number of in florescences per plant (0.723), and number of fruit per inflorescence (0.822) (Souza et al. 2012). Narolia et al. (2012) recorded a smaller difference between the phenotypic and genotypic CV for NB and NFR per plant, regarding that these variables are less influenced by the environment. On the other hand, differences between such coefficients were higher for fruit yield per plant, indicating that this characteristic is strongly influenced by the environment.

The genotypic coefficient of determination $\left(\mathrm{h}^{2}\right)$ observed for NB, NFR, and productivity was high (Table 2), showing that these characteristics are not influenced by environmental factors, and may be selected in earlier generations.

The highest values observed in regard to the coefficient of genotypic determination were: $74.88 \%$ for NB, $83.14 \%$ for NFR at 63 DAT, and $75.81 \%$ for productivity. Heritability is part of the variability found depending on additive effects of the genes. The selection of genotypes will be harder the higher the variability from the environment compared to total variability (Borém and Miranda, 2013).

The hybrids Kátia, AP-533, SVR-453 and the lines CVR 1, CVR 3, CVR 4, CVR 5, CVR 21, and CVR 22 did not differ, and were the most productive (Figure 1). In fact, these

Genetics and Molecular Research 16 (2): gmr16029540 
genotypes differed $(\mathrm{P} \leq 0.01)$ between the lines CVR 2, CVR 6, CVR 7, CVR 8, CVR 9, CVR 10, CVR 11, CVR 12, CVR 13, CVR 14, CVR 15, CVR 16, CVR 17, CVR 18, CVR 19, and CVR 20, which had the lowest productivity and did not differ from each other.

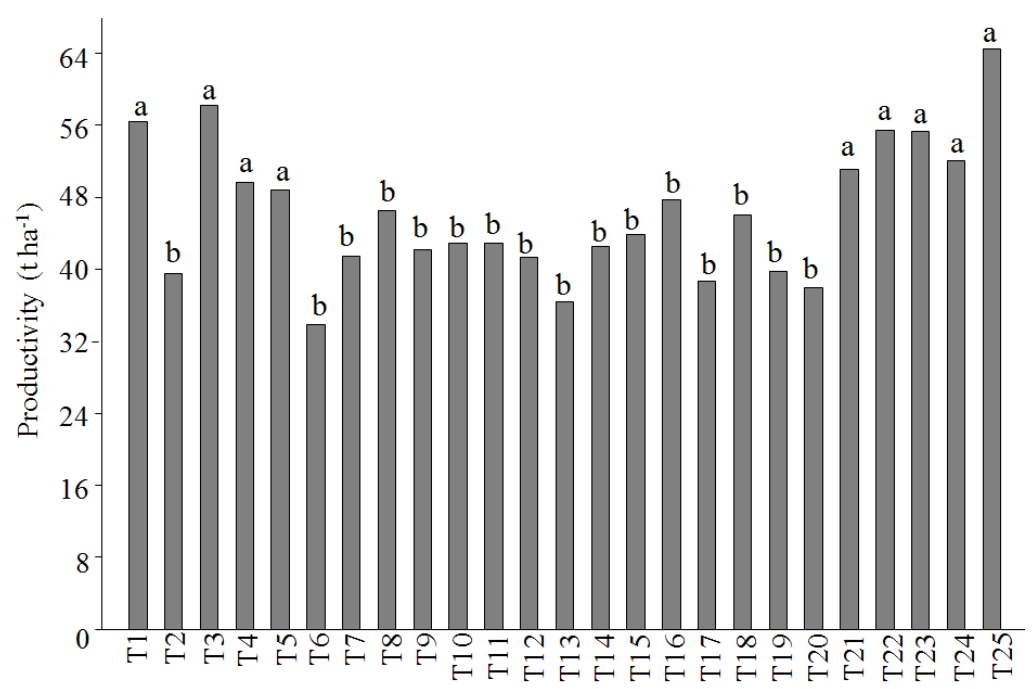

Figure 1. Average productivity of fruit of 25 industrial tomato genotypes in Goiânia, GO, harvest 2014. Means followed by different letters differ statistically by $\mathrm{F}$ and Scott-Knott tests at $5 \%$ probability level. The residuals had a normal distribution according to the Kolmogorov-Smirnov test, the variances were homogeneous according to the Levene test, and the additivity of the blocks was evaluated using the Tukey additivity test.

Reis et al. (2013) cultivating tomato in a protected system, obtained a maximum productivity at 70 days after transplant of $4.48 \mathrm{t} / \mathrm{ha}$, a value of productivity lower than the observed in this study. The highest productivity recorded for this study as for the hybrid Kátia (64.43 t/ha) follower by the lines CVR 3 (58.18 t/ha), CVR 1 (56.43 t/ha), CVR 22 (55.39 t/ ha), by the hybrids AP-533 (55.34 t/ha) and SVR-0453 (52.02 t/ha), and the lines CVR 21 (51.04 t/ha), CVR 4 (49.62 t/ha), and CVR 5(48.79 t/ha).

In commercial tomato crops, producers use 37,000 plants/ha, with spacing between plants from 0.34 to $0.37 \mathrm{~m}$ in double line under center pivot or $0.23 \mathrm{~m}$ between plants in a single line (Jacinto et al., 2012). High productivity levels are reached in such conditions, surpassing $100 \mathrm{t} / \mathrm{ha}$. The following productivity values would be reached if the lines evaluated in this study had been planted according to commercial planting standards and considering 30,000 plants/ha: CVR 1 (126.98 t/ha), CVR 2 (88.91 t/ha), CVR 3 (130.92 t/ha), CVR 4 (111.65 t/ha), CVR 5 (109.78 t/ha), CVR 6 (76.26 t/ha), CVR 7 (93.13 t/ha), CVR 8 (104.71 t/ha), CVR 9 (94.82 t/ha), CVR 10 (96.59 t/ha), CVR 11 (96.60 t/ha), CVR 12 (92.99 t/ha), CVR 13 (81.88 t/ha), CVR 14 (95.66 t/ha), CVR 15 (98.76 t/ha), CVR 16 (107.29 t/ha), CVR 17 (87.13 t/ha), CVR 18 (103.63 t/ha), CVR 19 (89.38 t/ha), CVR 20 (85.35 t/ha), CVR 21 (114.84 t/ha), CVR 22 (124.63 t/ha), and the hybrids AP-533 (124.52 t/ha), SVR-0453 (117.04 t/ha), and Kátia (144.98 t/ha).

Schwarz et al. (2013) evaluated the agronomic performance of different tomato hybrids in low cultivation, and observed a total yield ranging from 37.2 to $112.5 \mathrm{t} / \mathrm{ha}$ in the first year 
(2009/2010) and 37.8 to 78.5 t/ha in the second year (2010/2011), and the hybrid Granadero stood out with the highest production in both years. Figueiredo et al. (2016) evaluated different genotypes of tomato for industrial processing and calculated an average productivity for the hybrids AP- 529 and Tinto of 44.39 and 59.55 t/ha, respectively. Galvão et al. (2013) analyzed industrial tomato hybrids with spacing of $1.5 \mathrm{~m}$ between rows and $0.30 \mathrm{~m}$ between plants under different types of ground covering, and recorded a productivity of $81.97 \mathrm{t} / \mathrm{ha}$ for the hybrid AP-529, 79.62 t/ha for AP-533, 65.33 t/ha for Kátia, and 57.69 t/ha for Sicílio in the fallow area. The results obtained in this study support those reported by the aforementioned authors. In this study, the productivity of the hybrids AP-533 and Kátia were 55.34 and 64.43 $\mathrm{t} / \mathrm{ha}$, respectively, and the spacing between plants was 1.5 and $0.5 \mathrm{~m}$.

Wamser et al. (2012) evaluated the productivity in an indeterminate tomato hybrid subjected to dense cultivation, and observed that tomato grafting stalking one stem per plant, increased commercial fruit yield when compared to stalking two stems per plant. Tiwari et al. (2013) observed that the number of leaf branches exerts an indirect positive effect on the yield of tomato crops. Peil et al. (2014) observed higher proportion of dry matter in the fruit of tomato genotypes type "Red Cherry"despite of the stems. Raju et al. (2014) found higher fruit weight in plants with smaller number of fruits, which is associated with the inverse relationship between fruit weight and number of fruits per plant.

The variation in productivity among lines was homogeneous (Figure 2) showing the hierarchical clustering by the agglomerative method of the farthest neighbor. The analysis of the dendrogram allows the researcher to assess the degree of similarity between genotypes or between two distinct groups. Groups are determined subjectively by establishing a cut-off point in the dendrogram when there are important changes in levels and regard prior information that the researcher has on the material analyzed (Cruz et al., 2012).

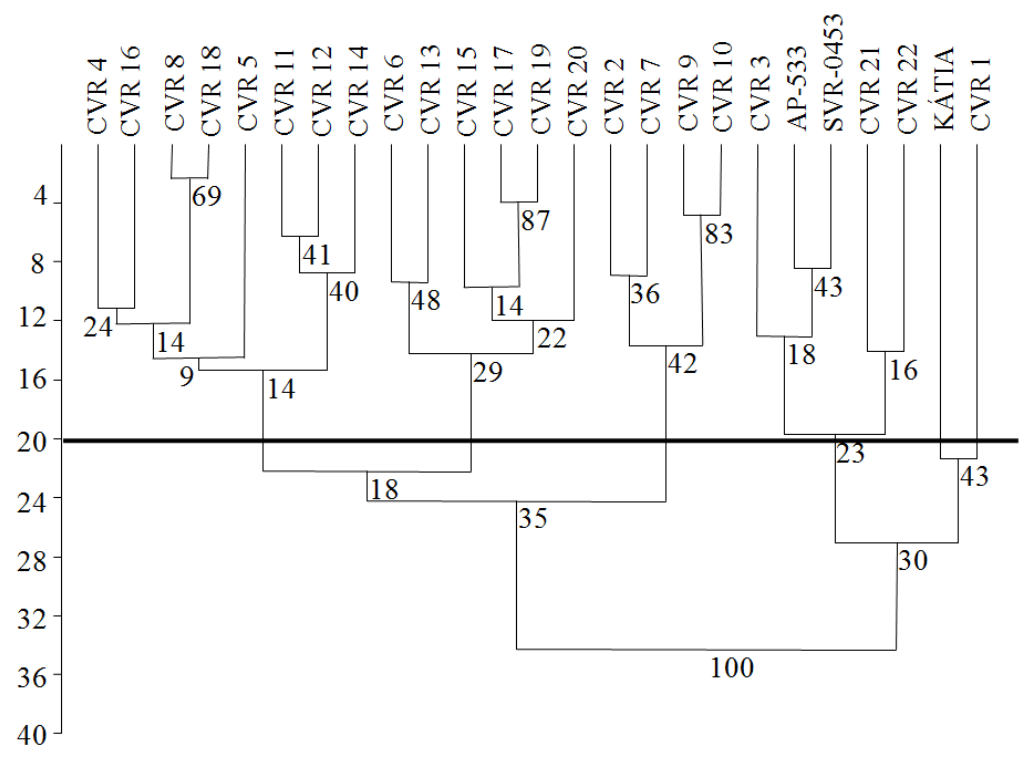

Figure 2. Dendrogram of genetic dissimilarities between 25 tomato genotypes, obtained by the method "hierarchical of the farthest neighbor" based on productivity.

Genetics and Molecular Research 16 (2): gmr16029540 
Six groups were formed when performing a cut-off considering $20 \%$ of dissimilarity. The first and largest group encompassed the lines CVR 4, CVR 16, CVR 8, CVR 18, CVR 5, CVR 11, CVR 12, and CVR 14 (32\% of the genotypes). The second group included the lines CVR 6, CVR 13, CVR 15, CVR 17, CVR 19, and CVR 20 and the third grouped the lines CVR 2, CVR 7, CVR 9, and CVR 10. The lines CVR 3, CVR 21, and CVR 22 and the hybrids AP-533 and SVR-0453 were similar and constituted the fourth group. The hybrid Kátia and the strain CVR 1 had the highest genetic diversity representing the fifth and sixth groups, respectively.

The similarity between lines and commercial hybrids, as well as genetic diversity among the genotypes presented shows the possibility of using these lines in genetic enhancement as a source of germplasm to obtain hybrids. The genotypes present in the last groups exhibited a greater divergence compared to the first groups, enabling its use for programs of breeding among more productive groups (Cruz et al., 2012).

The most productive genotypes (CVR 1, CVR 3, CVR 4, CVR 5, CVR 21, CVR 22 and the hybrids AP-533, SVR-453, and Kátia) also had the highest amount of leaf branches and flower racemes, except for CVR 1 and CVR 5, which had fewer leaf branches and flower racemes. This demonstrates that the amount of branches implies a greater production of flower racemes and consequently greater fruit production. On the other hand, a lesser amount of leaf branches produce a smaller NFR. However, the fruits are larger when compared to the fruits produced by plants with larger architecture. This is explained by the amount of assimilates directed to the fruits. The smallest amount of vegetative and/or reproductive organs implies an increase in leaf area, which increases the production of assimilates to be allocated to the fruit. Fruit development is characterized as the main reproductive drain (Peil et al., 2014).

PCA (Figure 3) showed that principal component 1 was responsible for the variability among the genotypes, comprising $60.93 \%$ of the variance. Principal component 2 represented $32.78 \%$ of the variance. These major components involve more than $80 \%$ of the total variation available proving that its use is satisfactory in genetic diversity studies (Cruz et al., 2012).

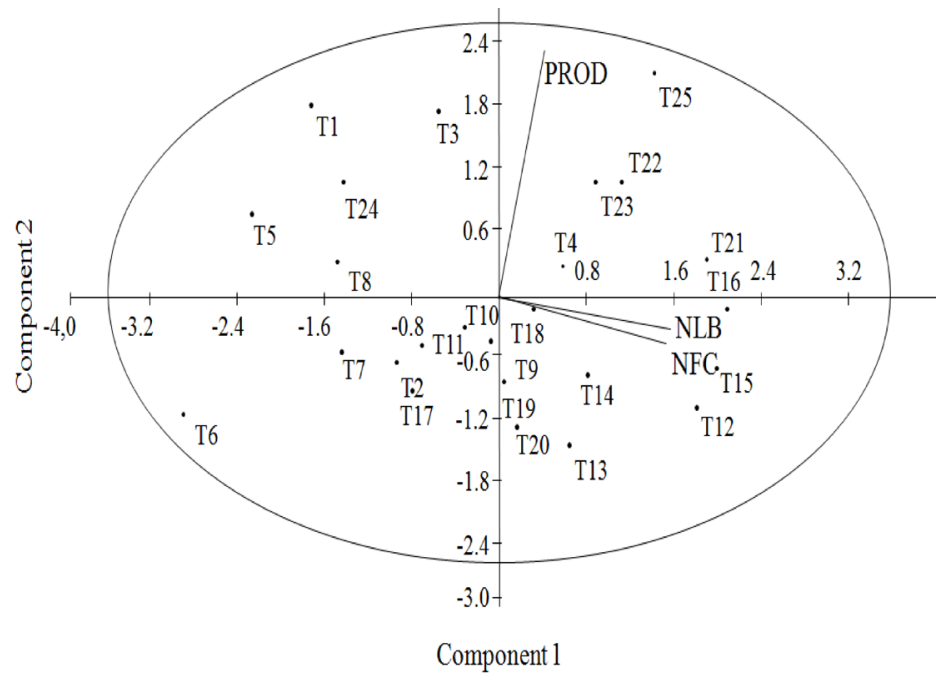

Figure 3. Graphic dispersion of the scores of the main components one and two for 25 tomato genotypes evaluated in regard to three traits.

Genetics and Molecular Research 16 (2): gmr16029540 
The variables NB and NFR were considered to be similar because the axes had the same direction (Figure 3). The lines CVR 4, CVR 12, CVR 14, CVR 15, CVR 16, and CVR 18 were correlated with NB and NFR, presenting the largest amount of leaf branches and flower racemes. Productivity is not directly related to these vegetative and reproductive traits, at is related with NB and NFR in a $90^{\circ}$ angle. The yield showed greatest contribution to the total variation among the genotypes, being the closest vector to the unit circle.

Five groups were formed, the first with the lines CVR 4, CVR 21, CVR 22 and the hybrids AP-533 and Kátia, which had the highest productivity values. The first group contrasts with the group formed by the genotypes CVR 1, CVR 3, CVR 5, CVR 8, and SVR-0453. Two groups were formed in the third quadrant, one with the lines CVR 2, CVR 7, CVR 10, CVR 11, and CVR 17 and another only with CVR 6. The fifth group was formed in the fourth quadrant, with the lines CVR 9, CVR 12, CVR 13, CVR 14, CVR 15, CVR 16, CVR 18, CVR 19, and CVR 20, which had high values of leaf branches and flower racemes.

The increase in the number of leaf branches per plant led to the increase in flower racemes and fruit (Yasmeen et al., 2014). Rivas et al. (2012) evaluated four tomato cultivars and reported that the cultivar Miramar had the highest NFR and produced more fruit; however, lighter in weight. This explains the lack of correlation between productivity and NB and NFR observed in the PCA.

The present study demonstrated that lines CVR 4, CVR 21, and CVR 22 had the best development of the branches, flower racemes, and productivity. The lines with the highest productivity were CVR 1, CVR 3, CVR 4, CVR 5, CVR 21, and CVR 22.

\section{Conflicts of interest}

The authors declare no conflict of interest.

\section{ACKNOWLEDGMENTS}

The authors thank CVR Plant Breeding, the field staff of Universidade Federal de Goiás, Bayer CropScience, and CAPES for the support given.

\section{REFERENCES}

AGRIANUAL (Anuário da Agricultura Brasileira) (2016). Tomate. 21th edn. Informa Economics FNP, São Paulo. Alvarenga MAR (2013). Tomate: produção em campo, casa de vegetação e hidroponia. 2nd edn. Universidade Federal de Lavras, Lavras.

Balestre M (2012). Mapeamento Bayesiano de múltiplos caracteres: efeitos pleiotrópicos no estudo da herança dos componentes da produção em milho. Doctoral thesis, Universidade Federal de Lavras, Lavras. Available at [http:// repositorio.ufla.br/handle/1/4747].

Borém A and Miranda GV (2013). Herdabilidade. In: Melhoramento de plantas (Borém A and Miranda GV, eds.). Universidade Federal de Viçosa, Viçosa.

Cruz CD (2013). Genes - a software package for analysis in experimental statistics and quantitative genetics. Acta Sci. Agron. 35: 271-276 http://dx.doi.org/10.4025/actasciagron.v35i3.21251.

Cruz CD, Regazzi AJ and Carneiro PCS (2012). Modelos biométricos aplicados ao melhoramento genético. 4th edn. Universidade Federal de Viçosa, Viçosa.

Doorembos J and Kassam AH (1979). Yield response to water (FAO Irrigation and Drainage Paper, 33). FAO, Rome.

EMBRAPA (Empresa Brasileira de Pesquisa Agropecuária) (2013). Sistema brasileiro de classificação de solos. 3rd edn. Embrapa, Brasília.

Ferreira DF (2011). Sisvar: a computer statistical analysis system. Cienc. Agrotec. 35: 1039-1042.

Genetics and Molecular Research 16 (2): gmr16029540 
Figueiredo AST, Resende JTV, Faria MV, Paula JT, et al. (2016). Agronomic evaluation and combining ability of tomato inbred lines selected for the industrial segment. Hortic. Bras. 34: 86-92. http://dx.doi.org/10.1590/S0102$\underline{053620160000100013}$

Galvão AG, Resende JTV, Morales RGF, Lustosa SBC, et al. (2013). Tomato yield and soil chemical attributes depending on previous cover crops. Hortic. Bras. 31: 68-73. http://dx.doi.org/10.1590/S0102-05362013000100011

Gautam US, Negi RS, Singh R, Kaushik SS, et al. (2013). Participatory Evaluation of Tomato Varieties for Commercial Cultivation During Rainy Season Under Kaymore Plateau and Satpura Hills - Agro-Climatic Zone of Madhya Pradesh. J. Agric. Sci. 5: 238-241.

George B, Kaur C, Khurdiya DS and Kapoor HC (2004). Antioxidants in tomato (Lycopersium esculentum) as a function of genotype. Food Chem. 84: 45-51. http://dx.doi.org/10.1016/S0308-8146(03)00165-1

Guimarães CM, Stone LF, Oliveira JP, Rangel PHN, et al. (2011). Sistema radicular do arroz de terras altas sob deficiência hídrica. Pesq. Agr. Trop. 41: 126-134.

Guo Y, Fourcaud T, Jaeger M, Zhang X, et al. (2011). Plant growth and architectural moelling and its applications. Ann. Bot. (Lond.) 107: 723-727. http://dx.doi.org/10.1093/aob/mcr073

Hammer Ø, Harper DAT and Ryan PD (2007). PAST: Paleontological statistics software package for education and data analysis. Palaeontol. Electronica 4: 1-9.

IBGE (Instituto Brasileiro de Geografia e Estatística) (2013). Levantamento sistemático da produção agrícola: pesquisa mensal de previsão e acompanhamento das safras agrícolas no ano civil. Fundação Instituto Brasileiro de Geografia e Estatística. 26: 1-84 Available at [ftp://ftp.ibge.gov.br/Producao_Agricola/Levantamento_Sistematico_da_ Producao_Agricola_[mensal]/Fasciculo/2013/1spa_201308.pdf/].

Jacinto LU, Soares BB, Rangel R and Jacinto AFVU (2012). Transplantio e colheita mecanizada. In: Produção de tomate para processamento industrial (Clemente FMVT and Boiteux LS, eds.). Embrapa, Brasília.

Kris-Etherton PM, Hecker KD, Bonanome A, Coval SM, et al. (2002). Bioactive compounds in foods: their role in the prevention of cardiovascular disease and cancer. Am. J. Med. 113 (Suppl 9B): 71S-88S. PubMed http://dx.doi. org/10.1016/S0002-9343(01)00995-0

Ma YT, Wubs AM, Mathieu A, Heuvelink E, et al. (2011). Simulation of fruit-set and trophic competition and optimization of yield advantages in six Capsicum cultivars using functional-structural plant modelling. Ann. Bot. (Lond.) 107: 793803. PubMed http://dx.doi.org/10.1093/aob/mcq223

Mahapatra AS, Singh AK, Vani VM, Mishra R, et al. (2013). Inter-relationship for various components and path coefficient analysis in tomato (Lycopersicon esculentum Mill.). Int. J. Curr. Microbiol. App. 2: 147-152.

Meena OP and Bahadur V (2015). Genetic associations analysis for fruit yield and its contributing traits of indeterminate tomato (Solanum lycopersicum L.) germplasm under open field condition. J. Agric. Sci. 7: 148-163.

Mohamed SM, Ali EE and Mohamed TY (2012). Study of heritabilty and genetic variability among different plant and fruit characters of tomato (Solanum lycopersicon L.). IJSTR 1: 55-58.

Narolia KN, Reddy RVSK and Sujatha M (2012). Genetic architecture of yield and quality in tomato (Solanum lycopersicum). Agric. Sci. Dig 32: 281-285.

Nascimento WM, Melo PCT and Freitas RA (2012). Produção de sementes. In: Produção de tomate para processamento industrial (Clemente FMT and Boiteux LS, eds.). Embrapa, Brasília.

Peil RMN, Albuquerque Neto AAR and Rombaldi CV (2014). Densidade de plantio e genótipos de tomateiro cereja em sistema fechado de cultivo em substrato. Hortic. Bras. 32: 234-240. http://dx.doi.org/10.1590/S0102$\underline{05362014000200021}$

Pimentel-Gomes F (2009). Curso de estatística experimental. 15th edn. Fundação de Estudos Agrários Luiz de Queiroz, Piracicaba.

Quintana-Baquero RA, Balaquera-López HE, Álvarez-Herrera JG, Cárdenas-Hernández JF, et al. (2010). Efecto del número de racimos por planta sobre el rendimiento de tomate (Solanum lycopersicum L.). Rev. Colomb. Cienc. Hortic. 4: 199-208.

Raju B, Shivanand H, Puttaraju TB and Sudheesh NK (2014). Performance of tomato (Lycopersicon esculentum Mill.) hybrids with respect of yield and quality traits. Int. J. Sci. Nat 5: 313-318.

Reddy BR, Reddy MP, Begum H and Sunil N (2013). Cause and effect relationship for yield and shelf life attributes in exotic lines of tomato (Solanum lycopersicum L.). IOSR-JAVS 4: 53-55.

Reis LS, Azevedo CAV, Albuquerque AW and Josué FS, Junior. (2013). Índice de área foliar e produtividade do tomate sob condições de ambiente protegido. Rev. Bras. Eng. Agric. Ambient. 17: 386-391. http://dx.doi.org/10.1590/S1415$\underline{43662013000400005}$

Rivas MBP, Albarracín M, Moratinos H and Navas FZ (2012). Nota técnica: Rendimiento y calidad de fruto en cuatro cultivares de tomate (Solanum lycopersicum L.) bajo condiciones protegidas. Rev. Fac. Agron. LUZ 29: 395-412.

Genetics and Molecular Research 16 (2): gmr16029540 
Schwarz K, Resende JTV, Preczenhak AP, Paula JT, et al. (2013). Desempenho agronômico e qualidade físico-química de híbridos de tomateiro em cultivo rasteiro. Hortic. Bras. 31: 410-418. http://dx.doi.org/10.1590/S0102$\underline{05362013000300011}$

Seleguini A (2007). Uso de paclobutrazol na produção de mudas, no crescimento, produção e qualidade de frutos de tomateiro em ambiente protegido. Doctoral thesis, Universidade Estadual Paulista, Ilha Solteira. Available at [http:// acervodigital.unesp.br/handle/unesp/158905?locale=es_ES].

Souza LM, Melo PCT, Luders RR and Melo AMT (2012). Correlations between yield and fruit quality characteristics of fresh market tomatoes. Hortic. Bras. 30: 627-631. http://dx.doi.org/10.1590/S0102-05362012000400011

Tiwari JK, Tiwari AK and Mehta N (2013). Selection strategies for fruit yield in tomato (Solanum lycopersicum L.). Int. J. Veg. Sci. 40: 23-27.

Wamser AF, Mueller S, Suzuki A, Becker WF, et al. (2012). Produtividade de híbridos de tomate submetidos ao cultivo superadensado. Hortic. Bras. 30: 168-174. http://dx.doi.org/10.1590/S0102-05362012000100028

Yasmeen A, Nouman W, Basra SMA, Wahid A, et al. (2014). Morphological and physiological response of tomato (Solanum lycopersicum L.) to natural and synthetic cytokinin sources: a comparative study. Acta Physiol. Plant. 36: 3147-3155. http://dx.doi.org/10.1007/s11738-014-1662-1

Genetics and Molecular Research 16 (2): gmr16029540 